\title{
LAPORAN KEUANGAN UNTUK MENILAI KINERJA KEUANGAN PT. BANK MANDIRI TBK. DAN ENTITAS ANAK
}

\author{
Helmi Herawati \\ Program Studi Akuntansi \\ Universitas Prof DR Hazairin SH Bengkulu \\ helmiherawati77@gmail.com
}

\begin{abstract}
ABSTRAK
Helmi Herawati; Penilaain kinerja keuangan bank didasarkan pada tiga jenis rasio yaitu rasio likuiditas bank, rasio solvabilitas bank dan rasio rentabilitas bank. Persaingan antar bank dalam menghimpun dana dari masyarakat dan menyalurkan dana dari masyarakat dalam bentuk kredit oleh bank komersial akan semakin ketat. Persaingan antar bank dalam praktiknya banyak bank yang kurang hati-hati ataupun menyimpang dari aturan-aturan yang berlaku dalam dunia bisnis perbankan. Tujuan penelitian adalah untuk mengetahui kinerja keuangan PT Bank Mandiri Tbk dan entitas anak berdasarkan rasio keuangan Bank. Jenis penelitian ini merupakan penelitian komparatif, berdasarkan ketiga rasio tersebut diatas menunjukkan PT Bank Mandiri Tbk dan entitas anak periode 2013 dan 2014 dalam posisi baik
\end{abstract}

\begin{abstract}
ABSRACT
Helmi Herawati; The bank's financial performance assessment is based on three types of the bank liquidity ratio, the bank's solvability ratio and bank profitability ratio. Competition between banks in collecting funds from the public and channel funds from the public in the form of loans by commercial banks will be more stringent. Competition among banks in practice many banks are less careful, or deviate from the rules that apply in the world of banking business. The research objective was to determine the financial performance of PT Bank Mandiri, Tbk and its subsidiaries based on financial ratios of the Bank. This type of research is a comparative study, based on three ratios mentioned above indicates PT Bank Mandiri, Tbk and its subsidiaries periods of 2013 and 2014 in good position
\end{abstract}

Keywords: Financial Statements, The Financial Performance Of The Bank's Financial Ratios

\section{PENDAHULUAN}

Laporan keuangan merupakan proses akuntansi dan salah satu sarana penting untuk mengkomunikasikan informasi keuangan kepada pihak-pihak luar perusahaan. Laporan keuangan juga sebagai sarana evaluasi dari pekerjaan bagian akuntansi, tetapi untuk selanjutnya laporan keuangan tidak hanya sebagai sarana evaluasi saja tetapi juga sabagai dasar untuk menentukan atau menilai posisi keuangan (Pongoh: 2013)

Persaingan antar bank dalam menghimpun dana dari masyarakat dan menyalurkan dana dari masyarakat dalam bentuk kredit oleh bank komersial semakin ketat. Persaingan antar bank dalam praktiknya banyak bank yang kurang hati-hati ataupun menyimpang dari aturan-aturan yang berlaku dalam dunia bisnis perbankan (Kumaedi:2014)

Sektor perbankan merupakan sektor yang sangat maju dalam beberapa tahun terakhir. Kemajuan ini juga diiringi dengan kemajuan teknologi dan meningkatnya ilmu pengetahuan serta adanya kesadaran dalam hal pendidikan. Berdasarkan laporan keuangan dapat dihitung jumlah rasio keuangan bank yang juga bisa dijadikan patokan kesehatan bank (Booklet perbankan Indonesia). 


\section{TINJAUAN PUSTAKA \\ Laporan Keuangan}

PSAK No. 1 (revisi 2009) menyatakan laporan keuangan adalah suatu penyajian terstruktur dari posisi keuangan dan kinerja keuangan suatu entitas. Kasmir (2008:7) laporan keuangan adalah laporan yang menunjukkan kondisi keuangan perusahaan pada saat ini atau dalam suatu periode tertentu.laporan keuangan menunjukkan kondisi perusahaan saat ini adalah merupakan kondisi terkini.

Kondisi perusahaan terkini adalah keadaan keuangan perusahaan pada tanggal tertentu (untuk neraca) dan periode tertentu (untuk laporan laba rugi). Biasanya laporan keuangan dibuat per periode, misalnya tiga bulan, atau enam bulan untuk kepentingan internal perusahaan dalam hal ini PT Bank Mandiri Tbk dan entitas anak. Sementara itu, untuk laporan lebih luas dilakukan satu tahun sekali. Disamping itu dengan adanya laporan keuangan dapat diketahui posisi terkini setelah laporan keuangan tersebut dianalisis.

Menurut Tunggal(1994:40) ikatan akuntan Indonesia (IAI )bekerja sama dengan Bank Indonesia pada tahun 1992 telah berhasil menyusun standar khusus Akuntansi Perbankan Indonesia (SKAPI)agar laporan keuangan Bank dapat disajikan secara lebih Informatif dan wajar sehingga berbagai pihak yang berkepentingan dapat memperoleh gambaran yang lebih akurat.tepat tentang keadaan keuangan dan usaha bank.

Hal-hal yang diatur dalam SKAPI antara lain:

I. Standar khusus laporan keuangan bank
a. Pengukuran dalam nilai uang
b. Laporan keuangan bank
c. Neraca
d. Laporan komitmen dan kontinjensi
e. Perhitungan laba rugi
f. Laporan perubahan posisi keuangan
g. Catatan ata laporan keuangan
h. Laporan keuangan gabungan dan konsolidasi
i. Laporan keuangan interim

II. Standar khusus akuntansi pendapatan dan beban
a. Pengakuan pendapatan dan beban bunga
b. Pengakuan pendapatan dan beban atas komisi dan provisi
c. Pengakuan pendapatan dan beban atas transaksi valuta asing

III. Standar khusus akuntansi aktiva
a. Kas
b. Giro pada bank Indonesia
c. Giro pada bank lain
d. Surat-surat berharga
e. Kredit yang diberikan
f. Penyertaan
g. Aktiva lain-lain

IV. Standar khusus akuntansi kewajiban dan modal
a. Giro
b. Kewajiban segera lainnya
c. Tabungan
d. Deposito berjangka
e. Sertifikat deposito
f. Pinjaman yang diterima
g. Kewajiban lain-lain
h. Pinjaman subordinasi
i. Modal pinjaman
j. Modal 
V. Standar khusus akuntansi komitmen dan kontinjensi

a. Komitmen

b. kontinjensi

laporan keuangan bank dibuat untuk emmenuhi kepentingan berbagai pihak, laporan ini disusun berdasarkan PAI dan SKAPI yang terdiri dari :

a. Neraca

Menurut Munawir (2001:13) neraca adalah laporan yang sistematis tentang aktiva, hutang serta modal dari suatu perusahaan pada suatu saat tertentu.

Tujuan nerca adalah untuk emnunjukkan posisi keuangan suatu perusahaan pada suatu tanggal tertentu

b. laporan komitmen dan kontijensi

laporan ini wajib disusun secara sistematis, sehingga dapat emmeberikan gambaran mengenai posisi komitmen dan kontinjensi.

Menurut Tunggal (1994: 44) komitmen adalah suatu ikatan atau kontrak berupa janji yang tidak dapat dibatalkan secara sepihak dan harus dilaksanakan apabila persyaratan yang disepakati bersama dipenuhi.

Kontinjensi adalah tagihan atau kewajiban bank yang kemungkinan timbulnya tergantung pada terjadi atau tidak terjadinya satu atau lebih peristiwa dimasa yang akan dating.

c. perhitungan laba rugi

menurut Munawir (2001:26) laporan lab rugi merupakan suatu laporan yang sistematis tentang penghasilan, biaya, rugi laba yang diperoleh suatu perusahaan selam periode tertentu.

d. laporan perubahan posisi keuangan

menurut Tunggal (1994:45) laporan posisi keuangan harus disusun berdasarkan konsep kas selama periode laporan. Laporan ini harus menunjukkan semua aspek penting dari kegiatan bank, tanpa memandang apakah transaksi tersebut berpengaruh langsung pada kas.

e. catatan atas laporan keuangan

menurut Tunggal (1994:45) bank juga wajib mengungkapkan dalam catatan tersendiri mengenai posisi devisa neto menurut jenis mata uang serta aktivitas-aktivitas lain.

\section{Kinerja Keuangan}

Fahmi (2012:2) menyatakan kinerja keuangan adalah suatu analisis yang dilakukan untuk melihat sejauh mana suatu perusahaan telah melaksanakan dengan menggunakan aturan-atauran pelaksanaan keuangan dengan baik dan benar. Seperti dengan membuat suatu laporan keuangan yang telah memenuhi standard dan ketentuan dalam SAK (standar akuntansi keuangan) atau GAAP (general accepted accounting principle).

\section{Rasio Keuangan}

Menurut Munawir (2001:64) rasio menggambarkan suatu hubungan atau perimbangan (mathematical relationship) antara suatu jumlah tertentu dengan jumlah tertentu dengan jumlah yang lain, dan dengan menggunakan alat analisa berupa ratio ini akan dapat menjelaskan atau member gambaran kepada penganalisa tentang baik atau buruknya keadaan atau posisi keuangan suatu perusahaan terutama apabila angka ratio tersebut dibandingkan dengan angka ratio pembanding yang digunakan sebagai standard.

Menurut Kasmir (2008:104) rasio keuangan merupakan kegiatan membandingkan angka-angka yang ada dalam laporan keuangan dengan cara membagi satu angka dengan angka lainnya. Perbandingan dapat dilakukan antara satu komponen dengan komponen dalam satu laporan keuangan atau antar komponen yang ada diantara laporan keuangan. Kemudian angka 
yang diperbandingkan dapat berupa angka-angka dalam satu periode maupun beberapa periode.

\section{Jenis-jenis rasio Bank}

Menurut Kasmir (2008: 216) untuk mengetahui kondisi keuaangan suatu bank dapat dilihat laporan keuangan yang disajikan oleh suatu bank secara periodic. Adapun rasio keuangan bank sebagai berikut:

1. Rasio likuiditas bank

Rasio ini bertujuan untuk mengukur seberapa likuid suatu bank dalam melayani nasabahnya. Dalam rasio ini terdiri dari beberapa jenis yaitu:
a. Quick ratio,
b. Investing policy ratio,
c. Banking ratio,
d. Assets to loans ratio,
e. Investment portfolio ratio,
f. Cash ratio,
g. Loan to deposit ratio,
$\mathrm{h}$. Investment risk ratio,
i. Liquidity risk ratio,
j. Credit risk ratio,
k. Deposit risk ratio.

2. Rasio solvabilitas bank

Rasio ini bertujuan untuk mengukur efektivitas bank dalam mencapai tujuannya. Dalam rasio ini terdiri dari beberapa jenis yaitu:
a. Primary ratio,
b. Risk assets ratio,
c. Secondary risk ratio,
d. Capital ratio,
e. Capital risk,
f. Capital adequancy ratio,
g. Gross yield on total assets,
h. Gross profit margin on total assets,
i. Net income on total assets.

3. Rasio rentabilitas bank

Rasio rentabilitas bank merupakan rasio yang digunakan untuk mengukur tingkat efisiensi usaha dan profitabiliatas yang dicapai oleh bank dalam suatu periode tertentu. Rasio ini terdiri dari:
a. Gross profit margin,
b. Net profit margin,
c. Return on equity capital,
d. Return on total assets,
e. Rate return on loan,
f. Interest margin on earning assets,
g. Interest margin on loan,
h. Laverage multiplier,
i. Assets utilization,
j. Interest expense ratio,
k. Cost of fund, Cost of money,
l. Cost of loanable fund,
m. Cost of operable fund,
n. Cost of efficiency. 


\section{Hubungan rasio keuangan dengan kinerja keuangan}

Fahmi (2012:50) menyatakan rasio keuangan dan kinerja perusahaan mempunyai hubungan yang erat. Rasio keuangan sangat banyak jumlahnya dan setiap rasio itu mempunyai kegunaanny masing masing. Bagi investor akan melihat rasio dengan penggunaan yang paling sesuai dengan analisis yang akan ia lakukan. Jika rasio tersebut tidak mempresentasikan tujuan dari analisis yang akan ia lakukan maka rasio tersebut tidak akan dipergunakan, karena dalam konsep keuangan dengan namanya fleksibelitas. Jadi dapat ditarik pemahaman bahwa hubungan antara analisis rasio keuangan dengan kinerja keuangan adalah dengan menggunakan analisis rasio keuangan maka perusahaan dapat merencanakan dan mengatur segala kebutuhan perusahaan untuk mengukur kekuatan dan kelemahan dalam mencapai dan meningkatkan apa yang di cita-citakan perusahaan (Amy0 rahmi).

\section{METODE PENELITIAN Jenis penelitian}

Jenis penelitian ini merupakan penelitian komparatif, dengan melakukan perbandingan (komparasi) kinerja PT Bank Mandiri (persero) TBK. Dan Entitas Anak tahun 2013 dan 2014 dengan menggunakan rasio keuangan bank.

Prosedur penelitian

1. Mengumpulkan teori yang berhubungan dengan analisis laporan keuaangan

2. Mencari data yang akan digunakan yaitu laporan keuaangan Bank mandiri

3. Menganalisis dengan mnggunakan rasio keuangan bank

4. Memberiakan kesimpulan sehingga dapat menjadi masukan bagi perusahaan

Dalam melakukan penelitian ini digunakan laporan keuangan konsolidasi PT Bank Mandiri Tbk Dan Entitas Anak periode 2013 dan 2014

\section{PEMBAHASAN}

\section{Analisis rasio keuangan menurut laporan Bank}

1. Rasio likuiditas bank

a. Quick Ratio

Rasio ini mengukur kemampuan bank dalam memenuhi kewajibannya terhadap para deposan.

Tabel 1. Quick Ratio PT. Bank Mandiri TBK dan entitas anak

\begin{tabular}{|l|l|l|l|l|}
\hline Tahun & Cash assets (a) & Total deposit (b) & $\begin{array}{l}\text { Quick ratio (c) } \\
=\mathrm{a} / \mathrm{b}\end{array}$ & $\begin{array}{l}\text { Quick ratio } \\
(\%)\end{array}$ \\
\hline 2013 & 110.756 .856 .000 .000 & 449.718 .040 .000 .000 & 0,2463 & $24,63 \%$ \\
\hline 2014 & 126.132 .948 .000 .000 & 576.325 .801 .000 .000 & 0,2188 & $21,88 \%$ \\
\hline
\end{tabular}

Sumber: Data yang telah diolah

Tabel 1 diketahui pada tahun 2013 sebesar 24,63\% dan pada tahun 2014 terjadi penurunan nilai rasio menjadi $21,88 \%$

b. Investing Policy Ratio

Rasio ini digunakan untuk mengukur kemampuan bank dalam melunasi kewajibannya pada deposannya dengan cara melikuidasi surat-surat berharga yang dimilikinya.

Tabel 2. Investing policy ratio PT. Bank Mandiri Tbk dan entitas anak

\begin{tabular}{|l|l|l|l|l|}
\hline Tahun & Securities (a) & Total deposit(b) & IPR (c) = a/b & IPR(\%) \\
\hline 2013 & 87.786 .735 .000 .000 & 449.718 .040 .000 .000 & 0,1952 & $19,52 \%$ \\
\hline 2014 & 93.817 .929 .000 .000 & 576.325 .801 .000 .000 & 0,1627 & $16,27 \%$ \\
\hline
\end{tabular}

Sumber; Data yang telah diolah 
Tabel 2 diketahui pada tahun 2013 sebesar 19,52\% dan terjadi penurunan pada tahun 2014 menjadi $16,27 \%$

c. Cash Ratio

Rasio ini digunakan untuk mengukur kemampuan bank dalam melunasi kewajiban yang harus segera dibayar dengan harta likuid yang dimiliki bank.

Tabel. 3. Cash ratio PT. Bank Mandiri Tbk dan entitas anak

\begin{tabular}{|l|l|l|l|l|}
\hline Tahun & Liquid assets (a) & $\begin{array}{l}\text { Short term } \\
\text { borrowing (b) }\end{array}$ & $\begin{array}{l}\text { cash ratio } \\
\text { (c)=a/b }\end{array}$ & cash ratio(\%) \\
\hline 2013 & 620.506 .517 .000 .000 & 116.250 .802 .000 .000 & 5,3376 & $533,76 \%$ \\
\hline 2014 & 720.372 .579 .000 .000 & 123.042 .656 .000 .000 & 5,8546 & $585,46 \%$ \\
\hline
\end{tabular}

Sumber: Data yang telah diolah

Tabel 3 diketahui pada tahun 2013 sebesar 533,76\% dan terjadi kenaikan menjadi $585,46 \%$ pada tahun 2014

d. Liquidity Risk

Rasio ini digunakan untuk mengukur rasio yang akan dihadapi bank apabila gagal untuk memenuhi kewajibannya terhadap para deposannya.

Tabel 4. Liquidity Risk PT. Bank Mandiri Tbk. Dan entitas anak

\begin{tabular}{|c|c|c|c|c|}
\hline Tahun & Liquid asset (a) & $\begin{array}{l}\text { Short } \\
\text { borrowing (b) }\end{array}$ & Total deposit (c) & $\begin{array}{l}\text { Liquidity } \\
\text { risk } \quad(\%) \\
(d)=(a-b) / c\end{array}$ \\
\hline 2013 & 620.5 & 116.250 .802 .000 .000 & 449.7 & 112,13 \\
\hline 2014 & 720.372 .579 .000 .000 & 123.042 .656 .000 .000 & 576.325 .801 .000 .000 & 103,64 \\
\hline
\end{tabular}

Sumber: Data yang telah diolah

Tabel 4 diketahui pada tahun 2013 sebesar 112,13\% dan terjadi penurunan pada tahun 2014 manjadi 103,64 \%

e. Deposit Risk Ratio

Rasio ini digunakan untuk mengukur risiko kegagalan bank dalam membayar kembali deposannya.

Tabel 5. Deposit risk ratio PT Bank Mandiri Tbk dan entitas anak

\begin{tabular}{|l|l|l|l|l|}
\hline Tahun & Equity capital (a) & Total deposit (b) & $\begin{array}{l}\text { Deposit risk } \\
\text { ratio } \\
(\mathrm{c})=\mathrm{a} / \mathrm{b}\end{array}$ & $\begin{array}{l}\text { Deposit } \\
\text { risk ratio } \\
(\%)\end{array}$ \\
\hline 2013 & 29.142 .975 .000 .000 & 449.718 .040 .000 .000 & 0,0648 & 6,48 \\
\hline 2014 & 29.142 .975 .000 .000 & 576.325 .801 .000 .000 & 0,05057 & 5,057 \\
\hline
\end{tabular}

Sumber: data yang telah diolah

Tabel 5. diketahui pada tahun 2013 sebesar 6,48\% dan mengalami penurunan pada tahu 2014 menjadi 5,057\%.

2. Rasio solvabilitas bank

a. Primary Ratio

Rasio ini untuk mengukur permodalan yang dimilikin sudah memadai.

Tabel 6. Primary ratio PT Bank Mandiri Tbk dan entitas anak

\begin{tabular}{|l|l|l|l|l|}
\hline Tahun & Equity capital (a) & Total Asset (b) & $\begin{array}{l}\text { Primary } \\
\text { ratio } \\
\text { (c)=a/b }\end{array}$ & $\begin{array}{l}\text { primary } \\
\text { ratio (\%) }\end{array}$ \\
\hline 2013 & 29.142 .975 .000 .000 & 648.250 .177 .000 .000 & 0,0449 & 4,49 \\
\hline 2014 & 29.142 .975 .000 .000 & 757.039 .212 .000 .000 & 0,0385 & 3,85 \\
\hline
\end{tabular}

Sumber: Data yang telah diolah

Tabel 6 diketahui pada tahun 2013 sebesar 4,49\% dan mengalami penurunan pada tahun 2014 menjadi $3,85 \%$. 
b. Risk Assets Ratio

Rasio ini untuk mengukur kemungkinan penurunan risk assets.

Tabel 7. Risk assets ratio PT Bank Mandiri Tbk dan entitas anak

\begin{tabular}{|l|l|l|l|l|l|l|}
\hline Tahun & Equity capital (a) & Total Asset (b) & Cash asset(c) & Securities (d) & $\begin{array}{l}\text { RAR } \\
(\mathrm{e})=\mathrm{a} \\
(\mathrm{b}-\mathrm{c}-\mathrm{d})\end{array}$ & $\begin{array}{l}\text { RAR } \\
(\%)\end{array}$ \\
\hline 2013 & 29.142 .975 .000 .000 & 648.250 .177 .000 .000 & 110.756 .856 .000 .000 & 87.786 .735 .000 .000 & 0,0648 & 6,48 \\
\hline 2014 & 29.142 .975 .000 .000 & 757.039 .212 .000 .000 & 126.132 .948 .000 .000 & 93.817 .929 .000 .000 & 0,0543 & 5,43 \\
\hline
\end{tabular}

Sumber: Data yang telah diolah

Tabel 7 diketahui tahun 2013 sebesar 6,48\% dan mengalami penurunan pada tahun

2014 menjadi 5,43\%

c. Secondary Risk Ratio

Rasio ini diguanakan untuk mengukur penurunan asset yang mempunyai resiko lebih tinggi.

Tabel 8. Secondary risk ratio PT. Bank Mandiri Tbk dan entitas anak

\begin{tabular}{|c|c|c|c|c|}
\hline Tahun & Equity capital (a) & $\begin{array}{l}\text { Secondary risk Asset } \\
\text { (b) }\end{array}$ & $\begin{array}{ll}\text { secondary } & \text { risk } \\
\operatorname{ratio}(\mathrm{c})=\mathrm{a} / \mathrm{b} & \\
\end{array}$ & $\begin{array}{l}\text { SRR } \\
(\%)\end{array}$ \\
\hline 2013 & 29.142 .975 .000 .000 & 655.143 .765 .000 .000 & 0,0444 & 4,44 \\
\hline 2014 & 29.142 .975 .000 .000 & 765.241 .210 .000 .000 & 0,0381 & 3,81 \\
\hline
\end{tabular}

Sumber: Data yang telah diolah

Tabel 8 diketahui pada tahun 2013 sebesar 4,44\% dan mengalami penuruanan 3,81 pada tahun 2014 .

3. Rasio rentabilitas bank

a. Gross Profit Margin

Rasio ini digunakan untuk mengetahui presentasi laba dari kegiatan usaha murni dari banyak bank yang bersangkutan setelah dikurangi biaya-biaya.

Tebel 9. Gross profit margin PT. Bank Mandiri Tbk dan entitas anak

\begin{tabular}{|l|l|l|l|l|l|}
\hline Tahun & Operating income (a) & Operating expense (b) & Operating income (c) & $\begin{array}{l}\text { GPM } \\
(\mathrm{d})=(\mathrm{a}-\end{array}$ & $\begin{array}{l}\text { GPM } \\
\text { b) } / \mathrm{c}\end{array}$ \\
\hline 2013 & 55.670 .184 .000 .000 & 35.365 .850 .000 .000 & 55.670 .184 .000 .000 & 0,3647 & 36,47 \\
\hline 2014 & 68.993 .761 .000 .000 & 44.831 .293 .000 .000 & 68.993 .761 .000 .000 & 0,3502 & 35,02 \\
\hline
\end{tabular}

Sumber : Data yang telah diolah

Tabel 9 diketahui pada tahun 2013 sebesar 36,47\% dan mengalami penurunan menjadi $35,02 \%$ pada tahun 2014 .

b. Net Profit Margin

Rasio ini untuk mengukur kemampuan bank dalam menghasilkan net income dari kegiatan operasi pokoknya.

Tabel 10. Net profit margin PT. Bank Mandiri Tbk. Dan entitas anak

\begin{tabular}{|l|l|l|l|l|}
\hline Tahun & Net income (a) & $\begin{array}{l}\text { Operating expense } \\
(\mathrm{b})\end{array}$ & NPM (c)=a/b & $\begin{array}{l}\text { NPM } \\
(\%)\end{array}$ \\
\hline 2013 & 16.253 .598 .750 .000 & 35.365 .850 .000 .000 & 0,4596 & 45,96 \\
\hline 2014 & 18.139 .371 .750 .000 & 44.831 .293 .000 .000 & 0,4046 & 40,46 \\
\hline
\end{tabular}

Sumber: Data yang telah diolah

Tabel 10 diketahui pada tahun 2013 sebesar 45,59 dan mengalami penurunan pada tahun 2014 menjadi 40,46\%. 


\section{c. Return On Equity Capital}

Rasio ini digunakan untuk mengukur kemampuan manajemen bank dalam mengelola capital yang ada untuk mendapatkan net income.

Tebel 11. Return on equity capital PT Bank Mandiri Tbk dan etitas anak

\begin{tabular}{|l|l|l|l|l|}
\hline Tahun & Net income (a) & Equity capital (b) & ROU (c)=a/b & ROU(\%) \\
\hline 2013 & 16.253 .598 .750 .000 & 29.142 .975 .000 .000 & 0,5577 & 55,77 \\
\hline 2014 & 18.139 .371 .750 .000 & 29.142 .975 .000 .000 & 0,6224 & 62,44 \\
\hline
\end{tabular}

Sumber: Data yang telah diolah

Tabel 11 diketahui pada tahun 2013 sebesar 2013 sebesar 55,77\% dan mengalami kenaikan menjadi 62,44\% pada tahun 2014.

d. Gross Yield On Total Assets

Rasio ini untuk mengukur kemampuan manajemen menghasilkan income dari pengelolaan asset.

Tabel 12 Gross yield on total assets PT Bank Mandiri Tbk dan entitas anak

\begin{tabular}{|l|l|l|l|l|}
\hline Tahun & $\begin{array}{l}\text { operating income } \\
\text { (a) }\end{array}$ & Total assets (b) & $\begin{array}{l}\text { GYoTA } \\
\text { (c)=a/b }\end{array}$ & $\begin{array}{l}\text { GYoTA } \\
(\%)\end{array}$ \\
\hline 2013 & 35.365 .850 .000 .000 & 648.250 .177 .000 .000 & 0,0545 & 5,45 \\
\hline 2014 & 44.831 .293 .000 .000 & 757.039 .212 .000 .000 & 0,0592 & 5,92 \\
\hline
\end{tabular}

Sumber: Data yang telah diolah

Tabel 12 diketahui pada tahun 2013 sebesar 5,45 \% dan mengalami kenaikan menjadi 5,92\% pada tahun 2014.

\section{e. Net Income Total Assets}

Rasio ini untuk mengukur kemampuan manajemen dalam memperoleh profitabilitas dan manajerial efisiensi secara keseluruhan

Tabel 13. Net income total assets PT Bank Mandiri Tbk dan entitas anak

\begin{tabular}{|l|l|l|l|l|}
\hline Tahun & Net income (a) & Total assets (b) & NITA(c)=a/b & $\begin{array}{l}\text { NITA } \\
(\%)\end{array}$ \\
\hline 2013 & 16.253 .598 .750 .000 & 648.250 .177 .000 .000 & 0,0251 & 2,51 \\
\hline 2014 & 18.139 .371 .750 .000 & 757.039 .212 .000 .000 & 0,0239 & 2,39 \\
\hline
\end{tabular}

Sumber: Data yang telah diolah

Tabel 13 diketahui pada tahun 2013 sebesra 2,51\% dan mengalami penurunan menjadi 2,39\% pada tahun 2014.

\section{f. Laverage Multiplier}

Rasio ini digunakan untuk mengukur kemampuan manajemen dalam mengelola asetnya karena adanya biaya yang harus dikeluarkan akibat penggunaan aktiva.

Tabel 14. Laverage multiplier PT Bank Mandiri Tbk dan entitas anak

\begin{tabular}{|l|l|l|l|}
\hline Tahun & Total assets (a) & Total equity (b) & $\mathrm{LM}(\mathrm{c})=\mathrm{a} / \mathrm{b}$ \\
\hline 2013 & 648.250 .177 .000 .000 & 82.561 .316 .000 .000 & $7,85 \mathrm{kali}$ \\
\hline 2014 & 757.039 .212 .000 .000 & 97.331 .548 .000 .000 & $7,78 \mathrm{kali}$ \\
\hline
\end{tabular}

Sumber: Data yang telah diolah

Tebal 14. Diketahui pada tahun 2013 sebesar 7,85 kali dan mengalami penurunana menjadi 7, 78 kali pada tahun 2014. 


\section{g. Assets Utilization}

Rasio ini digunakan untuk mengetahui kemampuan manajemen suatu bank dalam mengelola asset dalam rangka menghasilkan operating income dan non operating income.

Tabel 15. Assets Utilization PT Bank Mandiri Tbk dan entitas anak

\begin{tabular}{|l|l|l|l|l|l|}
\hline Tahun & $\begin{array}{l}\text { Operating income } \\
\text { (a) }\end{array}$ & $\begin{array}{l}\text { Non operating } \\
\text { income (b) }\end{array}$ & Total assets (c) & $\begin{array}{l}\mathrm{AU}(\mathrm{d})=( \\
\mathrm{a}+\mathrm{b}) / \mathrm{c}\end{array}$ & $\mathrm{AU}(\%)$ \\
\hline 2013 & 35.365 .850 .000 .000 & 19.369 .000 .000 & 648.250 .177 .000 .000 & 0,0844 & 8,44 \\
\hline 2014 & 44.831 .293 .000 .000 & 239.295 .000 .000 & 757.039 .212 .000 .000 & 0,3753 & 37,53 \\
\hline
\end{tabular}

Sumber: Data yang telah diolah

Tabel 15 diketahui tahun 2013 sebesar 8,44\% dan mengalami peningkatan pada tahun 2014 menjadi 37,53 \%.

h. Interest Expense Ratio

Rasio ini digunakan untuk mengukur besarnya persentase antara bunga yang dibayar kepada para deposannya dengan total deposit yang ada di bank.

Tabel 16. Interest expense ratio PT Bank Mandiri Tbk dan entitas anak

\begin{tabular}{|l|l|l|l|l|}
\hline Tahun & Interest income (a) & Total deposit (b) & IER (c)=a/b & IER(\%) \\
\hline 2013 & 43.339 .930 .000 .000 & 449.718 .040 .000 .000 & 0,0963 & 9,63 \\
\hline 2014 & 55.092 .073 .000 .000 & 576.325 .801 .000 .000 & 0,0955 & 9,55 \\
\hline
\end{tabular}

Sumber: Data yang telah diolah

Tabel 16 diketahui pada tahun 2013 sebesar 9, $63 \%$ dan mengalami penurunan sedikit pada tahun 2014 menjadi 9,55\%.

\section{KESIMPULAN}

Kesimpulan dalam penelitian ini adalah:

1. Rasio likuiditas secara keseluruhan Bank Mandiri berada dalam keadaan yang baik, walaupun berfluktuasi. Semakin besar nilai rasio menandakan perusahaan dalam kondisi baik dan liquid serta bank mempunyai kemampuan dalam memenuhi kewajiaban jangka pendeknya pada saat ditagih. Dengan kata lain perusahaan dapat membayar kembali pencairan dana deposannya pada saat ditagih serta dapat mencukupi permintaan kredit yang telah diajukan

2. Rasio solvabilitas juga dalam posisi baik yang artinya posisi ini harus dipertahankan dan ditingkatkan supaya Bank Mandiri tidak mengalami kesulitan dalam mencari sumber dana untuk membiayai kegiatannya.

3. Rentabilitas juga dalam posisi baik. Hal ini dikarenakan Bank Mandiri mempunyai tingkat efisiensi usaha dan profitabilitas yang dapat dicapai.

\section{DAFTAR PUSTAKA}

Booklet Perbankan Indonesia 2009. www.bi.go.id. Sektor perekonomian Indonesia

Fahmi, Irham. 2012. Analisis laporan Keuangan. Alfabeta. Bandung.

http://amy01rahmi.blogspot.co.id/2012/12/pengaruh-rasio-keuangan-terhadap-nilai.html

Ikatan Akuntan Indonesia. 2009. Standar Akuntansi Keuangan. Salemba Empat, Jakarta.

Kumaedi, dkk. 2014. STAR - Study \& Accounting Research | Vol XI, No. 2

Kasmir. 2008. Analisis Laporan Keuangan. PT. Rajawali Pers. Jakarta. 
Munawir.s. 2001. Analisa Laporan Keuangan. Liberty. Yogyakarta

Tunggal, Amin wijaya. 1994. Dasar-Dasar Akuntansi Bank. Rineka Cipta. Jakarta

Pongoh Marsel. 2013. Analisis Laporan Keuangan Untuk menilai kinerja keuangan PT. Bumi Resources TBK. Jurnal EMBA Vol 1. 